John Carroll University

Carroll Collected

Sociology

2008

\title{
Wisdom, resilience and successful aging: Changing public discourses on living with dementia
}

Phyllis Braudy Harris

John Carroll University, pharris@jcu.edu

John Keady

Follow this and additional works at: http:// collected.jcu.edu/soc-facpub

Part of the Family, Life Course, and Society Commons, and the Medicine and Health Commons

\section{Recommended Citation}

Harris, Phyllis Braudy and Keady, John, "Wisdom, resilience and successful aging: Changing public discourses on living with dementia" (2008). Sociology. 9.

http://collected.jcu.edu/soc-facpub/9

This Editorial is brought to you for free and open access by Carroll Collected. It has been accepted for inclusion in Sociology by an authorized administrator of Carroll Collected. For more information, please contact connell@jcu.edu. 


\section{Wisdom, resilience and successful aging: Changing public discourses on living} with dementia

Phyllis Braudy Harris and John Keady

Dementia 2008 7: 5

DOI: $10.1177 / 1471301207085364$

The online version of this article can be found at:

http://dem.sagepub.com/content/7/1/5

Additional services and information for Dementia can be found at:

Email Alerts: http://dem.sagepub.com/cgi/alerts

Subscriptions: http://dem.sagepub.com/subscriptions

Reprints: http://www.sagepub.com/journalsReprints.nav

Permissions: http://www.sagepub.com/journalsPermissions.nav

Citations: http://dem.sagepub.com/content/7/1/5.refs.html

>> Version of Record - Feb 14, 2008

What is This? 


\section{Editorial}

Wisdom, resilience and successful aging: Changing public discourses on living with dementia

\section{PHYLLIS BRAUDY HARRIS John Carroll University, Cleveland, USA}

J O H N KE A DY University of Manchester/Bolton, Salford and Trafford Mental Health NHS Trust, UK

The concepts of wisdom, resilience and successful aging are not often spoken in the same sentence as the word dementia. In fact, many people might even think this sequencing is an oxymoron. Yet, as researchers, health/social care professionals and voluntary service personnel work more closely with people with dementia as co-researchers/inquirers and mentors (Harris, 2007; Keady, Williams, Hughes-Roberts, Quinn, \& Quinn, 2007) the connection of these three words to the lived experience of dementia gains increasing relevance and meaning.

One of the underlying goals of this journal is to assist in breaking down the stereotypes and stigma that surrounds a diagnosis of dementia, and its aftermath. Published articles throughout the seven-year existence of the journal attest to that effort, for example:

- 'Essay on a word: A lived experience of Dementia' (Sterin, 2002);

- 'Personal spirituality of persons with early-stage dementia' (Katsuno, 2003);

- 'Make it easy on yourself! Advice to researchers from someone with dementia on being interviewed' (Mckillop \& Wilkinson, 2004);

- 'Accuracy and consistency of responses from persons with cognitive impairment' (Whitlatch, Feinberg, \& Tucke, 2005);

- 'The role of advocacy in our adventure with Alzheimer's' (Knauss \& Moyer, 2006); and

- 'Participatory research: A method of process consent for persons with dementia' (Dewing, 2007).

Taken together, articles like these should cause us to pause and reconceptualize our understanding of the strengths and capabilities of people with dementia. 
As social scientists and health professionals we know that words, labels and attitudes can have a profound effect on perceptions, both selfperceptions and societal perceptions, which impact daily on people with dementia and their families. Kitwood's influential body of work, memorably synthesized into his award winning and seminal text Dementia reconsidered: The person comes first (Kitwood, 1997) set out the vision for a 'new culture' of dementia care to emerge, a culture where language, environment, positive person work and human values melded together to create a blueprint for a more positive vision of a life lived with dementia. In such a culture, opportunities exist for self-growth and 'rementia' to flourish (Kitwood, 1997).

In the USA, the national office of the Alzheimer's Association has made one of its goals 'to change the face of Alzheimer's disease'. To accomplish this endeavour, they are using celebrity spokespersons, such as David Hyde Pearce (of the television situation comedy Frasier fame) whose grandfather and father both were diagnosed with Alzheimer's disease. His discussion of his experiences with his family members humanizes the condition and makes people more accepting in their attitudes toward people with Alzheimer's. Another example is the work of The Federation of Quebec Alzheimer Societies (Girard \& Ross, 2005). The Societies are calling for the demise of the word 'dementia', based on the rationale that it really is not a definitive medical diagnosis and there is too much negative connotation imbued in the word that cannot be forgotten. Some notable neurologists, such as Peter Whitehouse are supportive of such an approach (Whitehouse, 2007), although the word dementia is embedded within medical and public discourse and will not easily slip out of our vocabulary and memories.

So what, exactly, does this appraisal amount to? Well, as editors of this journal, we are advocating for another approach, one that leads to a similar destination but plots its path through a more sensitive and appreciative lens. We need to start pairing words with positive images, such as 'wisdom', 'resilience' and 'successful aging', with 'dementia', 'Alzheimer's disease' and 'family care'. This can only be achieved by advocating for evidencebased research that tests the likelihood of this connection, using multiple types of research methodologies and cooperative methods in the process.

Some research in this area has been started (Beard, 2006; Harris, 2006; Scholl \& Sabat, 2007; Stuckey, 2006), which demonstrates that people with dementia can age successfully and examines various variables and conceptualizations that may affect this phenomenon. For example, Stuckey (2006) in his research suggests the phrase 'meaningful aging' as a more inclusive terminology than 'successful aging' and illustrates how people with Alzheimer's disease use religion and spirituality to achieve this state of being. Scholl and Sabat (2007) have examined the concepts of stereotyping and stereotype threat as understudied factors in dementia research 
and successful aging, which can influence the performance and the self of a person with Alzheimer's disease. Beard (2006) brings to the discourse the reminder that 'normal' and 'successful aging' may vary based on racial/ethnic backgrounds, as well as mental status. Harris (2006) has focused on the potential of the concept of resilience to move the thinking about successful aging forward by suggesting that resilience should be the goal for all older adults with or without dementia, not successful aging. However, these research studies are just a beginning and more research and theoretical conceptualizations are needed to move this agenda onto centre stage.

With the worldwide number of people with dementia now reaching 24 million and estimated to reach 80 million by 2040 (Alzheimer's Disease International, 2007), it has become imperative to change the 'master narrative' (Somers, 1994) of living with dementia that has consisted of 'loss', 'failure' and 'meaningless existence' and substitute it with more positive discourse and visual images, such as reflected in the title of this editorial. This is not being advocated to negate or diminish the heartwrenching impact of dementia on the person or the family. However, unless more positive imagery and discourse can be assimilated into the public consciousness, which shows the variability of people with dementia, adequate public policy and funding across the various stages of dementia will not occur. Social policy change is rarely solely based upon social science evidence, but more on public perception. For that to happen societal perception must be changed, and stoking the fire that initiates that change is our collective responsibility.

\section{References}

Alzheimer's Disease International (2007). Fact sheet: The prevalence of dementia. Retreived 29 June 2007 from http://www.alz.co.uk/adipublications.html

Beard, R. (2006, November). Successful according to whom? Comparing perceptions of aging across race and mental status. Paper presented at the 59th Annual Scientific Meeting of the Gerontological Society of America, Dallas, TX.

Dewing, J. (2007). Participatory research: A method of process consent for persons with dementia. Dementia: The International Journal of Social Research and Practice, 6(1), $11-26$.

Girard, R., \& Ross, N. (2005, September). Impact of words. Paper presented at the Alzheimer's Disease International Conference, Istanbul, Turkey.

Harris, P.B. (2006, November). Resilience: An undervalued concept in the debate about successful aging. Paper presented at the 59th Annual Scientific Meeting of the Gerontological Society of America, Dallas, TX.

Harris, P.B. (2007). People with early stage Alzheimer's disease as mentors: Developing a truly collaborative research process. Alzheimer's Care Quarterly, 8(1), 1-6.

Katsuno, T. (2003). Personal spirituality of persons with early-stage dementia. Dementia: The International Journal of Social Research and Practice, 2(3), 299-314. 
Keady, J., Williams, S., Hughes-Roberts, J, Quinn, P., \& Quinn, M. (2007). 'A changing life': Co-constructing a personal theory of awareness and adjustment to the onset of Alzheimer's disease. In M. Nolan, E. Hanson, G. Grant \& J. Keady (Eds.), User participation research in health and social care: Voices, values and evaluation. Maidenhead: Open University Press/McGraw Hill, 69-88.

Kitwood, T. (1997). Dementia reconsidered: The person comes first. Philadelphia, PA: Open University Press.

Knauss, J., \& Moyer, D. (2006). The role of advocacy in our adventure with Alzheimers' disease. Dementia: The International Journal of Social Research and Practice, 5(1), $67-72$.

Mckillop, J., \& Wilkinson, H. (2004). Make it easy on yourself! Advice to researchers from someone with dementia on being interviewed. Dementia: The International Journal of Social Research and Practice, 3(2), 117-126.

Scholl, J.M., \& Sabat, S.R. (2007). Stereotypes, stereotype threat and ageing: Implications for the understanding and treatment of people with Alzheimer's disease. Ageing and Society, 27, 1-29.

Somers, M.R. (1994). The narrative constitution of identity: A relational and network approach. Theory and Society, 23, 605-649.

Sterin, G.J. (2002). Essay on a word: A lived experience of Dementia. Dementia: The International Journal of Social Research and Practice, 1(1), 7-10.

Stuckey, J. (2006, November). Not 'success' but 'meaning': Dementia and meaningful aging. Paper presented at the 59th Annual Scientific Meeting of the Gerontological Society of America, Dallas, TX.

Whitlatch, C., Feinberg, L.F., \& Tucke, S. (2005). Accuracy and consistency of responses from persons with cognitive impairment. Dementia: The International Journal of Social Research and Practice, 4(2), 171-183.

Whitehouse, P.J. (2007). Editorial. Dementia: The International Journal of Social Research and Practice, 6(4), 459-462. 